Supplement of Atmos. Chem. Phys., 14, 5735-5747, 2014

http://www.atmos-chem-phys.net/acp-14-5735-2014/

doi:10.5194/acp-14-5735-2014-supplement

(C) Author(s) 2014. CC Attribution 3.0 License.

(c) (1)

Supplement of

\section{What controls the recent changes in African mineral dust aerosol across the Atlantic?}

D. A. Ridley et al.

Correspondence to: D. A. Ridley (daridley@mit.edu)

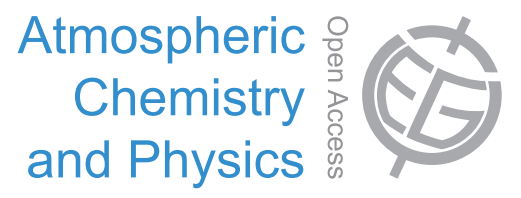

Atmospheric

and Physics 
3 Climatological evaluation of GEOS-Chem

4 Observational datasets

5 The MODIS instrument provides near daily coverage of the globe and AOD retrievals at $550 \mathrm{~nm}$

6 that are well validated against AERONET observations (Levy et al., 2010). The MODIS Deep Blue

7 retrieval is used to estimate AOD over bright surfaces (Hsu et al., 2004), providing complementary

8 observations in regions not covered by AERONET in the Sahara. In this study we use daily Level 3

9 MODIS observed AOD from the Aqua satellite (13:30 equatorial overpass, Collection 5) with the

10 Deep Blue retrieval where no standard retrieval is available.

11 The Aerosol Robotic Network (AERONET) is a well-established global network of sun photometers

12 used to derive aerosol optical depth (AOD) at a set of standard wavelengths $(440,675,870$ and

$131020 \mathrm{~nm}$ ) on a daily basis (Holben et al., 1998). Almucantar measurements (a series of 14 measurements taken for multiple azimuth angles at the elevation of the sun) allow size and 15 scattering information to be estimated from the retrieved extinction, producing a measure of the contribution of fine $(<1 \mathrm{um}$ ) and coarse aerosol to the AOD (Dubovik et al., 2002). In this study,

17 we use daily AOD retrievals from eight AERONET sites across West Africa (locations shown on Fig.

18 2) between 2004 and 2008 to evaluate the model representation of AOD close to source.

\section{Evaluation of GEOS-Chem dust scheme over North Africa}

21 Several previous studies have assessed the skill of the DEAD dust scheme in the GEOS-Chem

22 model and show reasonable agreement with satellite and surface observations both close to 23 source and downwind (Duncan Fairlie et al., 2007; Generoso et al., 2008; Johnson et al., 2010; 
1 Ridley et al., 2012). Given the model alterations described in Sect. 2 (inclusion of a sub-grid wind

2 parameterization, a new source map and dynamic vegetation), we re-evaluate the model for

3 North Africa using AERONET observations and MODIS retrievals close to source and surface

4 concentrations downwind in Barbados. We use a five year simulation (2004 - 2008) with all

5 aerosol components included to allow for direct comparison with AOD observations from MODIS

6 and AERONET.

7 Figure S1 compares the normalized dust emissions for both the GOCART and geomorphic source

8 maps averaged over the period $2004-2008$, both scaled to give the same total emissions for the

9 region. The key source regions of the Bodélé Depression and in Central Sahara are well

10 represented in both, with more weighting given to the former when using the geomorphic source

11 map. Relative to the potential source regions outlined in (Formenti et al., 2011), five of the six

12 regions are represented in the current dust scheme; however, emissions from the region at the

13 Mali - Niger border $\left(20^{\circ} \mathrm{N}, 5^{\circ} \mathrm{E}\right)$ appear weak in both dust schemes. Another key difference is that

14 the area from which emissions can occur is broader in the geomorphic source map, with potential

15 emissions extending further south if vegetation cover permits. The dust emission frequency

16 derived from SEVIRI satellite observations by Schepanski et al. (2007) indicates that emissions are

17 possible from a broader region, in agreement with the geomorphic source map. While it has been

18 shown that geomorphic source maps can lead to erroneous dust emissions in the US as a result

19 of the vegetation-dependence (Fairlie et al., 2007; Zender et al., 2003), comparison between the

20 model and observations in Africa suggests that the new source function performs at least as well

21 as the original GOCART source function in this region. 
1 Figure S2 compares the seasonal AOD (averaged over $2004-2008$ ) observed by MODIS to the

2 GEOS-Chem simulation with the original and updated dust scheme. The spatial correlation

3 between model and MODIS coarse AOD over the dust source region in North Africa $\left(10^{\circ} \mathrm{N}-36^{\circ} \mathrm{N}\right.$,

$422.5^{\circ} \mathrm{W}-32.5^{\circ} \mathrm{E}$ ) is slightly improved in all five years when using the updated dust scheme, from

$5 \quad 0.72$ to 0.78 in winter and from 0.63 to 0.67 in summer. This improvement is largely the result of

6 the reduction in emissions from the West Coast relative to those from the Bodélé Depression

7 produced by the new source function and vegetation modulation. However, the fraction of 8 modeled AOD at the Bodélé Depression is still low relative to the observations; this contributes

9 to the regional model AOD low biases of $21 \%$ and $38 \%$ in winter and summer, respectively. We

10 find that suppression of emissions by soil moisture and vegetation is limited in the Bodélé region,

11 suggesting that MERRA surface winds are too weak to generate the large flux of dust observed,

12 particularly in August and September. Biomass burning aerosol below approximately $12^{\circ} \mathrm{N}$ during

13 the winter and sea salt aerosol in coastal regions may both influence the agreement with MODIS

14 and AERONET, but we expect these effects to be small relative to the dust aerosol that accounts

15 for over $70 \%$ of the annual AOD between $10^{\circ} \mathrm{N}$ and $36^{\circ} \mathrm{N}$ in the model, also observed in (Formenti

16 et al., 2008).

17 Figure S3 shows comparison of daily measurements at eight AERONET sites with the updated model AOD (including non-dust species) during the period 2004-2008. The temporal correlation averaged across the sites (and weighted by the number of observations) increases from 0.75 to

200.78 during winter, and increases from 0.66 to 0.72 in summer when using the updated dust

21 scheme. The RMS error relative to AERONET is reduced during the summer at all eight sites but

22 worsened slightly at Sahelian sites during the winter using the updated dust scheme. We find 
1 that including the sub-grid wind PDF reduces the RMS error across almost all sites and seasons

2 but the inclusion of the new source function and vegetation modulation masks this improvement

3 in winter, suggesting that wintertime source regions are now over-represented in the Sahel

4 (excluding the Bodélé Depression). While the total improvement relative to the observations is

5 small, the new dust emission scheme should be capturing more processes as it represents both

6 sub-grid winds and the modulation of dust emissions from vegetation changes. General

7 agreement with daily observations from the AERONET sites is good, with the majority of days

8 falling within a factor of 2 of the observations and seasonal correlation coefficients greater than

$9 \quad r=0.6$ for all but one location. In the Sahel, there is a tendency for the model to overestimate

10 the AOD during high aerosol loading (predominantly in winter) and underestimate the AOD in

11 summer, potentially from poor representation of dust emissions driven by local convective storm

12 down drafts, i.e. Haboobs (Marsham et al., 2011), or from poor representation of wind gustiness

13 and therefore a bias towards emission from synoptic air flow in the wintertime. Attribution of

14 the wintertime overestimation is confounded by the presence of biomass burning aerosol. In

15 addition, the AERONET sites are clustered in the Sahel biasing the comparison to this particular

16 region and underrepresenting the Sahara. Tamanrasset, located in the Sahara but perhaps not

17 representing the area well (Cuesta et al., 2008), indicates a similar picture to the Sahel with the model AOD biased high during winter and low during summer.

19 Figure 5 shows the comparison of both the original and updated dust model with a monthly 20 climatology of surface dust concentrations at the Barbados site over the period $1982-2008$. The

21 observed climatology shows a peak in the average concentration in June $\left(30 \mu \mathrm{gm}^{-3}\right)$ and a

22 minimum in December $\left(7.5 \mathrm{\mu gm}^{-3}\right)$, with greatest interannual variability between March and 
1 June. The updated source map shifts the peak in modeled concentration from July to June, in

2 better agreement with the observations, and also improves the seasonality by increasing the

3 summertime peak average concentration from $21.0 \mu \mathrm{gm}^{-3}$ to $26.0 \mathrm{\mu gm}^{-3}$ and decreasing the

4 wintertime average concentration slightly.

5 We also investigated the possibility of using the SEVIRI dust source activation frequency (DSAF)

6 to constrain the emissions in the model. We scaled the wind threshold for emission such that the

7 model produced the best fit with the number of dust event days per month, derived from four

8 years of SEVIRI observations (Schepanski et al., 2007). While the wind threshold scaling boosted

9 emissions from the Bodélé Depression during summer and reduced them in coastal regions,

10 which would be expected to improve the model based on Fig. 3, the improvement to the model

11 dust AOD was minimal when compared with both MODIS and AERONET. This suggests that the

12 efficacy of DSAF for improving the simulation of dust may be limited by the inability to consider

13 the size of the dust event, in agreement with (Tegen et al., 2013). Scaling the wind threshold for

14 emission may be masking errors in MERRA surface winds rather than providing useful

15 information on surface susceptibility to emission; therefore, we have chosen not to include the

16 DSAF scaling in the simulations used in this study.

17 The model exhibits little change in skill considering that the source regions have changed quite

18 dramatically between the standard and updated dust schemes. This suggests that the wind fields

19 dominate the agreement with observations, both in terms of the surface wind strength leading

20 to emissions and the large-scale transport across the continent. Achieving a higher fidelity dust

21 simulation therefore appears to rely more on an improvement of the wind fields than the

22 characterization of the surface properties. 


\section{References}

Cuesta, J., Edouart, D., Mimouni, M., Flamant, P. H., Loth, C., Gibert, F., Marnas, F., Bouklila, A., Kharef, M., OuchèNe, B., Kadi, M. and Flamant, C.: Multiplatform observations of the seasonal evolution of the Saharan atmospheric boundary layer in Tamanrasset, Algeria, in the framework of the African Monsoon Multidisciplinary Analysis field campaign conducted in 2006, J. Geophys. Res. Atmospheres, 113, doi:10.1029/2007JD009417, 2008.

Dubovik, O., Holben, B., Eck, T. F., Smirnov, A., Kaufman, Y. J., King, M. D., Tanre, D. and Slutsker, I.: Variability of absorption and optical properties of key aerosol types observed in worldwide locations, J. Atmospheric Sci., 59(3), 590-608, 2002.

Fairlie, T. D., Jacob, D. J. and Park, R. J.: The impact of transpacific transport of mineral dust in the United States, Atmos. Environ., 41(6), 1251-1266, 2007.

Formenti, P., Rajot, J. L., Desboeufs, K., Caquineau, S., Chevaillier, S., Nava, S., Gaudichet, A., Journet, E., Triquet, S., Alfaro, S., Chiari, M., Haywood, J., Coe, H. and Highwood, E.: Regional variability of the composition of mineral dust from western Africa: Results from the AMMA SOP0/DABEX and DODO field campaigns, J. Geophys. Res. Atmospheres, 113(D23), doi:10.1029/2008JD009903, 2008.

Formenti, P., Schütz, L., Balkanski, Y., Desboeufs, K., Ebert, M., Kandler, K., Petzold, A., Scheuvens, D., Weinbruch, S. and Zhang, D.: Recent progress in understanding physical and chemical properties of African and Asian mineral dust, Atmos Chem Phys, 11(16), 8231-8256, doi:10.5194/acp-11-8231-2011, 2011.

Generoso, S., Bey, I., Labonne, M. and Bréon, F.-M.: Aerosol vertical distribution in dust outflow over the Atlantic: Comparisons between GEOS-Chem and Cloud-Aerosol Lidar and Infrared Pathfinder Satellite Observation (CALIPSO), J. Geophys. Res., 113(D24), doi:10.1029/2008JD010154, 2008.

Holben, B. N., Eck, T. F., Slutsker, I., Tanre, D., Buis, J. P., Setzer, A., Vermote, E., Reagan, J. A., Kaufman, Y. J., Nakajima, T., Lavenu, F., Jankowiak, I. and Smirnov, A.: AERONET - A federated instrument network and data archive for aerosol characterization, Remote Sens Env., 66(1), 116, 1998.

Hsu, N. C., Tsay, S. C., King, M. D. and Herman, J. R.: Aerosol properties over bright-reflecting source regions, IEEE Trans Geosci Remote Sens., 42(3), 557-569, doi:10.1109/tgrs.2004.824067, 2004.

Johnson, M. S., Meskhidze, N., Solmon, F., Gassó, S., Chuang, P. Y., Gaiero, D. M., Yantosca, R. M., Wu, S., Wang, Y. and Carouge, C.: Modeling dust and soluble iron deposition to the South Atlantic Ocean, J Geophys Res, 115, D15202, 2010. 
1 Levy, R. C., Remer, L. A., Kleidman, R. G., Mattoo, S., Ichoku, C., Kahn, R. and Eck, T. F.: Global

2 evaluation of the Collection 5 MODIS dark-target aerosol products over land, Atmospheric

3 Chem. Phys., 10(21), 10399-10420, 2010.

4 Marsham, J. H., Knippertz, P., Dixon, N. S., Parker, D. J. and Lister, G. M. S.: The importance of 5 the representation of deep convection for modeled dust-generating winds over West Africa

6 during summer, Geophys. Res. Lett., 38(16), doi:10.1029/2011GL048368, 2011.

7 Ridley, D. A., Heald, C. L. and Ford, B.: North African dust export and deposition: A satellite and

8 model perspective, J. Geophys. Res., 117(D2), doi:10.1029/2011JD016794, 2012.

9 Schepanski, K., Tegen, I., Laurent, B., Heinold, B. and Macke, A.: A new Saharan dust source 10 activation frequency map derived from MSG-SEVIRI IR-channels, Geophys Res Lett, 34(18), 5, 11 doi:L18803 10.1029/2007gl030168, 2007.

12 Tegen, I., Schepanski, K. and Heinold, B.: Comparing two years of Saharan dust source activation 13 obtained by regional modelling and satellite observations, Atmos Chem Phys, 13(5), 2381-2390, 14 doi:10.5194/acp-13-2381-2013, 2013.

15 Zender, C. S., Newman, D. and Torres, O.: Spatial heterogeneity in aeolian erodibility: Uniform, 16 topographic, geomorphic, and hydrologic hypotheses, J Geophys Res-Atmos, 108(D17), 15, 17 doi:4543 10.1029/2002jd003039, 2003. 


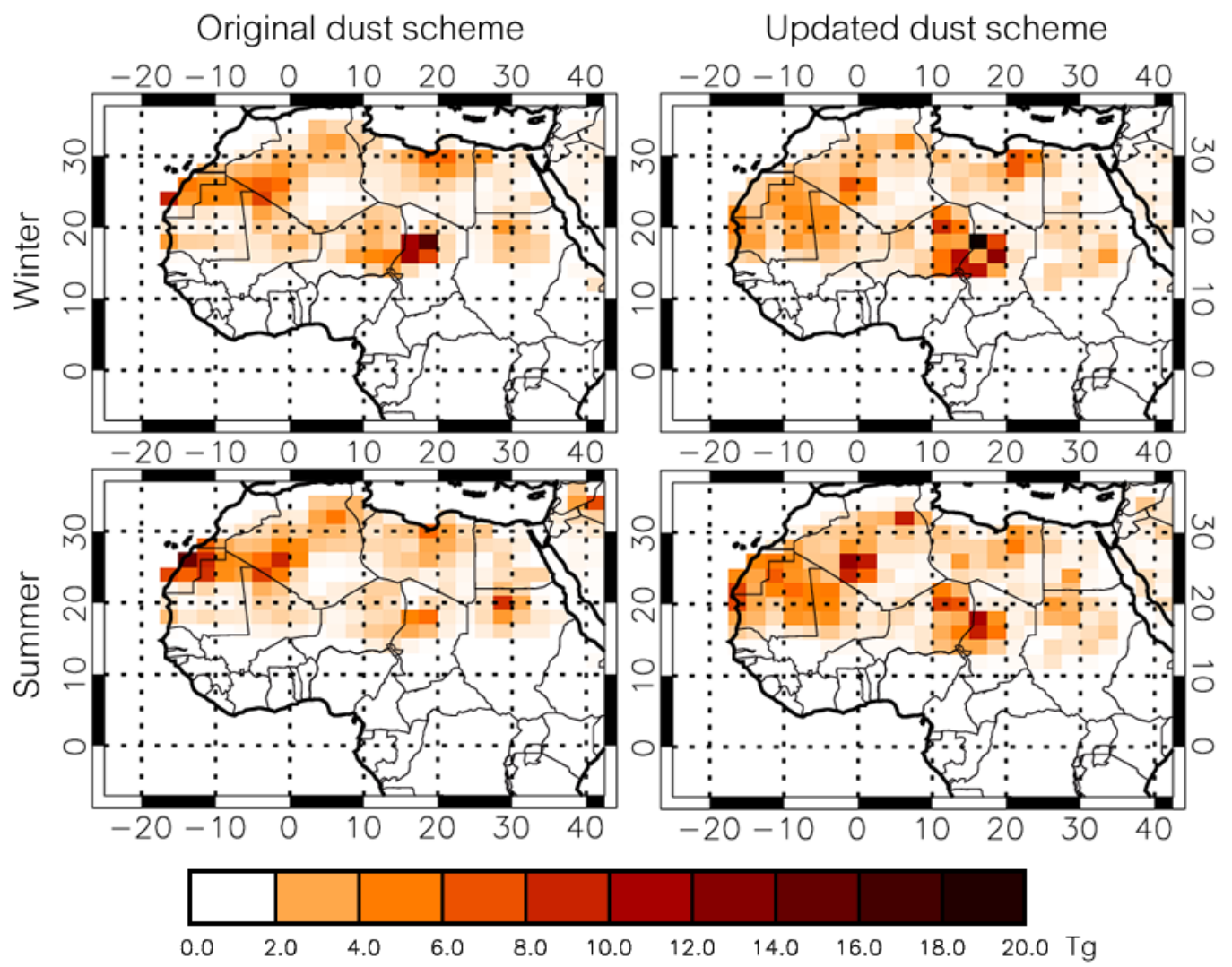

2 Figure S1 - Dust emissions averaged over the period $1982-2008$ are shown for the region of interest based on (a) the GOCART dust source map, the default in GEOS-Chem, and (b) the newly

4 implemented source map, derived from levelness and roughness surface properties (Koven et al., 52008 ) and responding to dynamic vegetation cover derived from the NDVI product from AVHRR. 


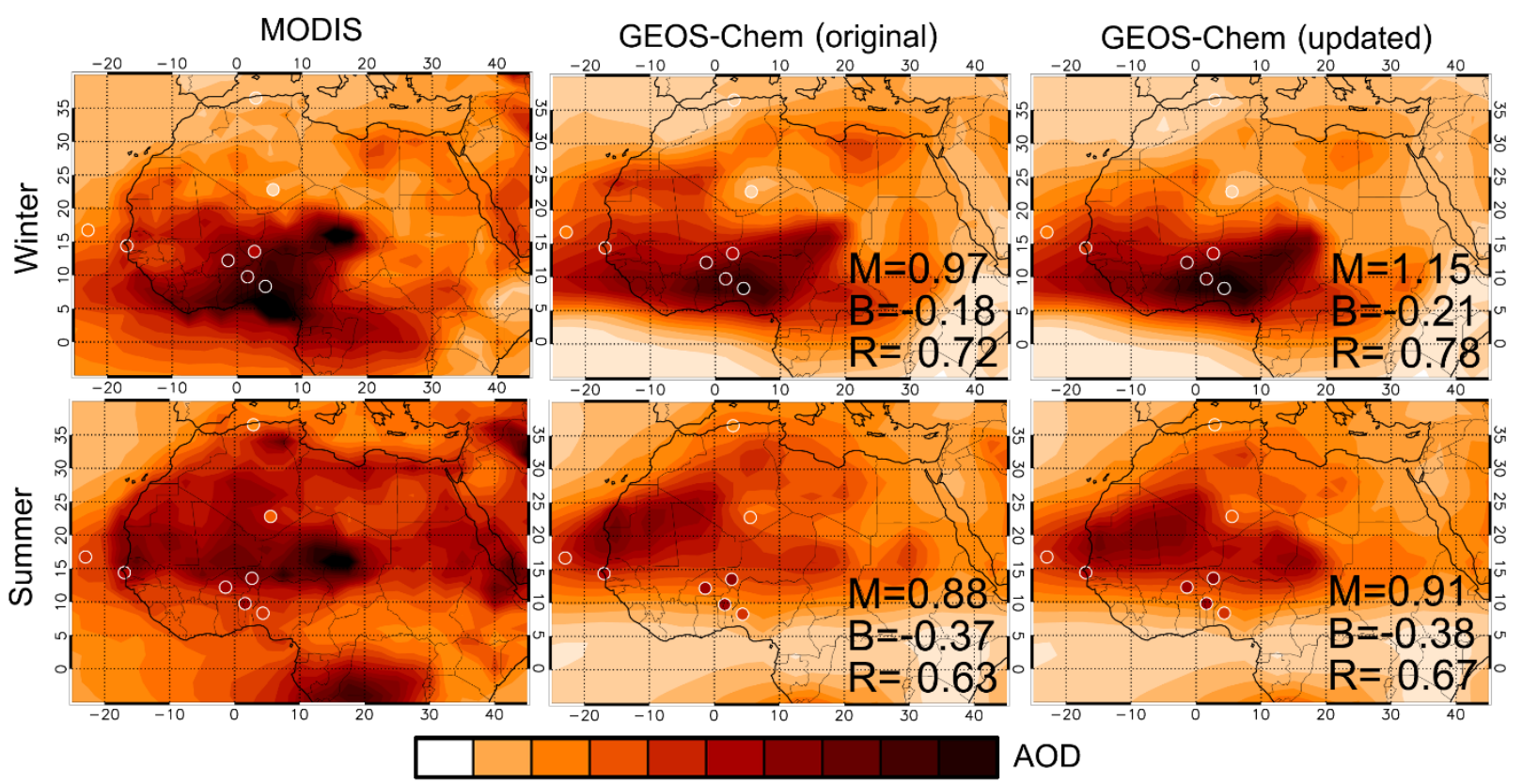

2 Figure S2 - AOD averaged over 2004 to 2008 for winter (DJFM) and summer (AMJJAS) is shown

3 for MODIS, the original model and the model with updated dust scheme. Average AERONET AOD

4 for all available data is displayed in the circles. Both versions of the model have the same total

5 dust emissions and identical emissions for all other aerosol. Regression coefficient (R), slope (M)

6 and bias (B) with MODIS are indicated for both models. 

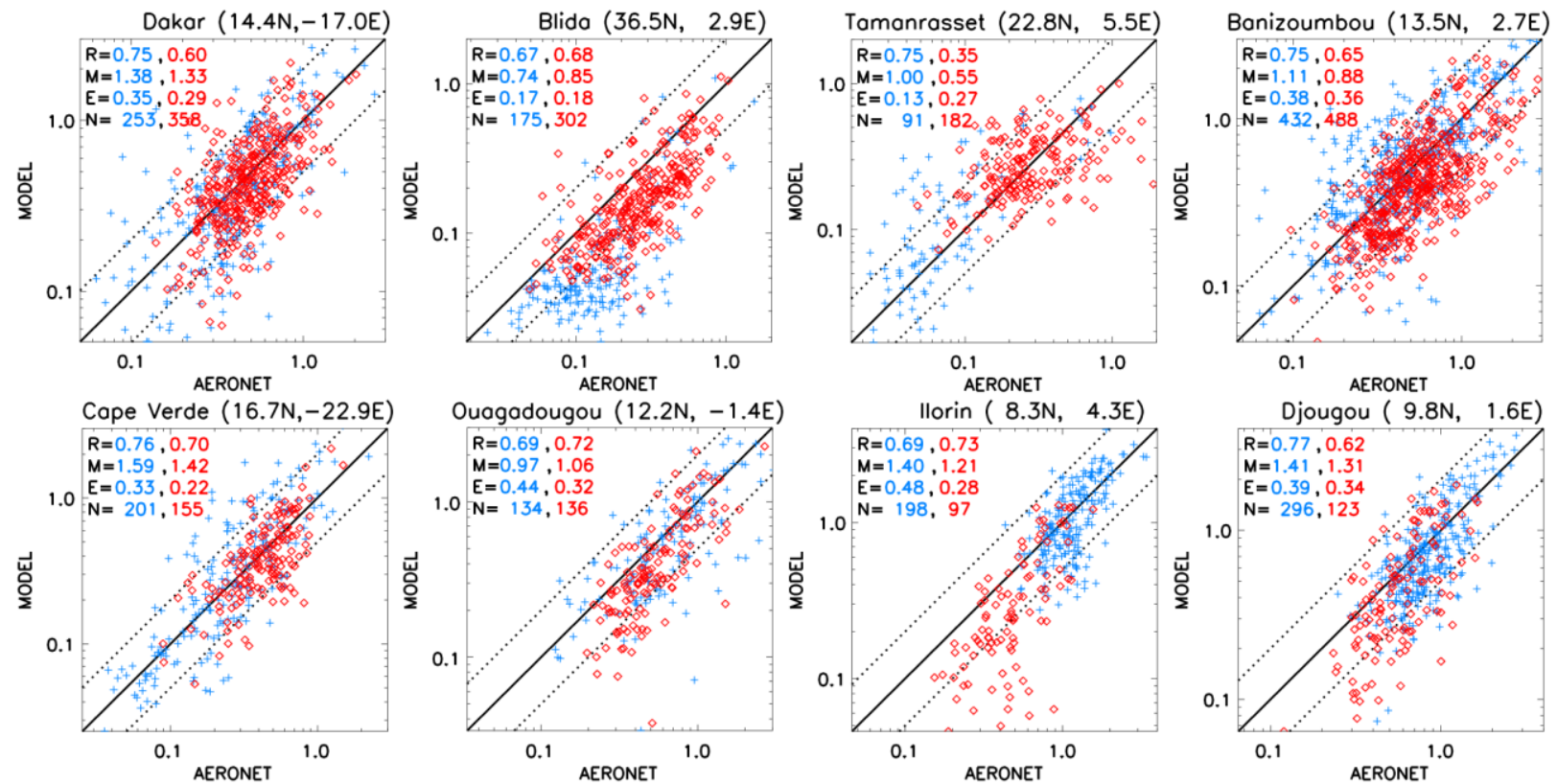

Figure S3 - Daily AOD between 2004 and 2008 from AERONET and the model (all aerosol) with updated dust scheme are displayed for 8 AERONET sites in Africa. Days during the winter and summer seasons are shown as blue crosses and red diamonds, respectively, the solid line represents the 1:1 agreement and dashed lines indicate the 2:1 boundaries. Regression

7 (blue) and summer (red).
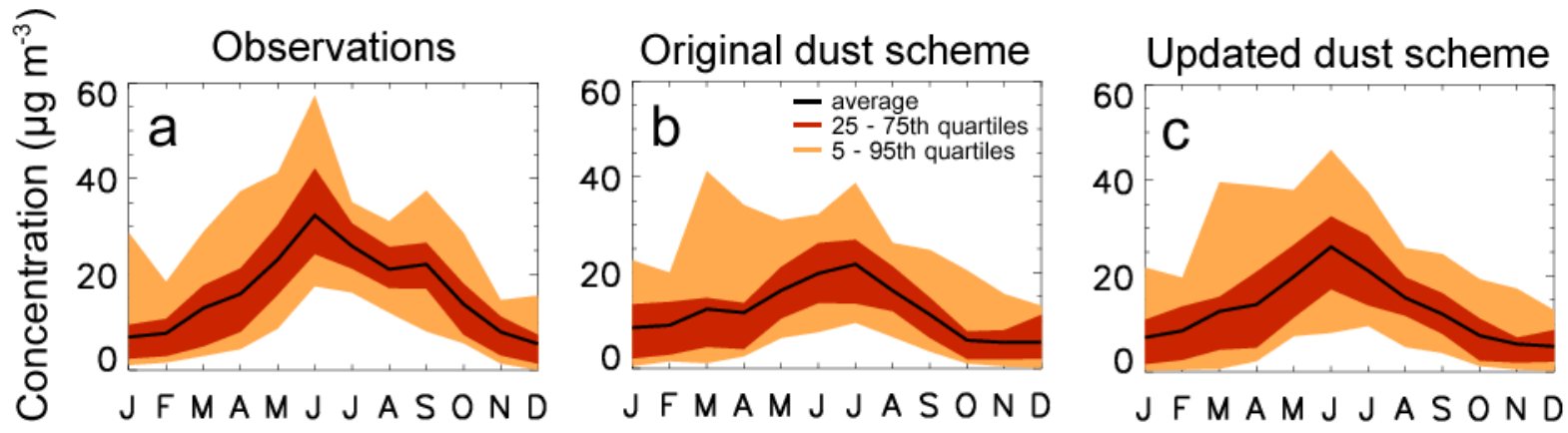
$1 \quad$ Figure S4 - Climatological (1982 - 2008) monthly surface dust concentrations are displayed for

2 (a) observations made at Ragged Point in Barbados, (b) the baseline GEOS-Chem model, and (c)

3 the GEOS-Chem model with sub-grid wind parameterization and Koven dust source map. The

4 black line indicates the monthly mean and the red and orange shading corresponds to the $25^{\text {th }}$

5 to $75^{\text {th }}$ and $5^{\text {th }}$ to $95^{\text {th }}$ quantile ranges, respectively. 